\title{
Policies and Views of the UN and Western Nations on Al-Shabaab and Its Recruitment Strategies
}

\author{
Abdi O. Shuriye \\ Department of Science, International Islamic University \\ Jalan Gombak 53100, Malaysia \\ E-mail: shuriye@iium.edu.my
}

Received: December 26, 2011

Accepted: February 15, $2012 \quad$ Published: March 1, 2012

doi:10.5539/res.v4n1p220

URL: http://dx.doi.org/10.5539/res.v4n1p220

\begin{abstract}
This research studies the policies and views of the United Nations and major Western nations on Al-Shabaab movement. The research also examines al-Shabaab's recruitment methods and strategies. The objective of the research is to broadly evaluate the reactions of al-Shabaab to Western policies on their political administration of Somalia. The research employs analytical methodology to arrive at inclusive conclusions. The importance of the study lies on the political imperativeness of the region and the UN failure to intervene, successfully, on its bloody, ideological and ethnic-based conflicts. As early as 1991 the UN intervened in Somalia's conflict but to this date all UN attempts to resolve Somalia's political predicament remained futile. Islamists came on board to Somalia's political fiasco in 2006 and they could remain for some time. What is remarkable to observe nonetheless, is their capriciously unpredictable political attitude. In the current political epoch of the Muslim world, groups like al-shabaab, Taliban and al-Qaeda seem out of touch with the new breed of comparatively young Muslim generation.
\end{abstract}

Keywords: Al-Shabaab, Somalia, Political Islam, United Nations, Western Nations, Peace, East Africa

\section{Introduction}

The fundamental question of this research is to ascertain the UN position and that of Western nations on al-Shabaab Movement. Al-Shabaab or full name, Harakat Al-Shabaab al-Mujahidin, or in English, The Youth Mujahidin al-Shabaab Movement, is a Somali ideologue Muslim men group who currently control much of Somalia. Al-ShabaabIt has been waging an open war against Somalia's transitional government and covert war on other Horn and East African nations. The international community has so far failed to contain the group. The theoretical framework of the research identifies the connection between the UN failure to contain or defeat al-Shabaab and its belief and approach on addressing on diverse perspectives including engagement and dialogue with the group. The UN has so far argued that al-Shabaab are direct threat to peace and security in the region and its Security Council Committee on Somalia has subsequently issued list of individuals identified pursuant to paragraph 8 of Resolution 1844 (2008), this is also pursuant to resolutions 751 (1992) and 1907 (2009).

The research also investigates the position of the Western influential powers including the US and European nations. The West is of the view that al-Shabaab intimidates and violets the Somali transitional government and threatens, on daily bases, the civil society activists working to bring about peace through political dialogue and reconciliation. On those clear grounds, al-Shabaab are listed in most of these nations as a terrorist group. However, it may not be possible to defeat al-Shabaab on military might alone. In fact, the present of East African troops on the ground is part of the problem.

The international community should honestly work on forming strong Transitional Federal Government. Currently the TFG has no functional capacity to govern as it controls only Mogadishu area. Without bring some semblance of order to the country it would also be unthinkable to create real possibility for peace.

\section{The United Nation's Efforts to Restrain al-Shabaab}

Historically speaking, intervention, be it political or military in Somali affairs, has so far proven futile. The United Nations decided to intervene in Somali predicament in late 1991 and their first action was imposing an 
arms embargo on the country. At the same time, the first diplomatic initiate was carried out where James Jonah, the under Secretary General for Political Affairs, visited Somalia and persuaded Ali Mahdi and General Aideed to hold talks in New York under the auspices of the UN, the organization of African Unity (OAU), the League of Arab States (LAS) and the Organization of Islamic Conference (OIC) (Sanderson Beck,). This was an opportunity missed like other noble chances of political weight.

There are few agreements done from there on including the establishment of the first UN peacekeeping operation in Somalia in April 1992. The mandate of the United Nations Operation in Somalia (UNOSOM) led by the Special Representative of the Secretary General (SRSG), Mohamed Sahnoun, to maintain a ceasefire throughout the country, promote reconciliation and a political settlement and provide urgent humanitarian assistance. However, the peace keeping mission of the UN, the UNOSOM, withdrew from Somalia in March 1995 having failed to achieve reconciliation and revive Somalia's collapsed state (Mark Bradbury and friends, 2009). After the withdrawal, the Secretary General established the United Nations Political Office for Somalia (UNPOS) to help him advance the cause of peace and reconciliation through contacts with Somali leaders, civic organizations and the States and organizations concerned. The UN continued to engage indirectly, monitoring the situation and providing periodic reports for the Secretary General from a base in Nairobi. However, the diplomatic initiative was left to regional countries and the European Union after five years. (UNPOS)

After a series of failure of the United Nations intervention and followed by collapse of serial peace talks between Somali factions, United Nations has declined to send peacekeepers to Somalia due to lack of peace in the country. However, since 2007 they have lent support to African mission in Somalia. Currently, the UN felt that they would engage war with Islamist fighters if they enter Somalia.

The UN had passed several resolutions on Somalia and it renewed or modified these resolutions. The Security Council of the United Nations, acting under Article 41 of the Charter of the United Nations, adopted several resolutions including Resolution 733 (1992) on January 23, 1992, Resolution 751 (1992) on April 24, 1992, Resolution 1356 (2001) on June 19, 2001, Resolution 1425 (2002) on July 22, 2002, Resolution 1725 (2006) on December 6, 2006, Resolution 1744 (2007) on February 20, 2007, Resolution 1772 (2007) on August 20, 2007 and Resolution 1844 (2008) on November 20, 2008. In recent years the Council deemed necessary to make regulations for enabling the measures set out in those resolutions to be effectively applied.

In relation to al-Shabaab, on 12th April 2010 the Security Council Committee on Somalia issued list of individuals and organizations identified pursuant to paragraph 8 of Resolution 1844 (2008), this is also pursuant to resolutions 751 (1992) and 1907 (2009).

Taking this position the UN has argued that al-Shabaab engaged in acts that directly threaten peace, security, or stability of Somalia, including but not limited to: acts that threaten the Djibouti Agreement of August 18, 2008, or the political process; and, acts that threaten the Transitional Federal Institutions (TFIs), the African Union Mission in Somalia (AMISOM), or other international peacekeeping operations related to Somalia.

The UN has also argued that al-Shabaab obstructed the delivery of humanitarian assistance to Somalia, or access to, or distribution of, humanitarian assistance in Somalia. According to the Statement by the Chairman of the Security Council Committee established pursuant to resolution 751 (1992) concerning Somalia to the Security Council delivered on 29 July 2009, al-Shabaab publicly and repeatedly claimed responsibility for the attacks by their forces on the Transitional Federal Government (TFG) and AMISOM. Al-Shabaab had also claimed responsibility for the killing of TFG officials, and on 19 July 2009 had raided and shut down the field offices of UNOPS, UNDSS and UNDP in the Bay and Bakool regions, in violation of paragraph 8 (c) of resolution 1844 (2008).

Other UN reports have suggested that al-Shabaab extort money from private companies and recruiting young people to join the fight against the government. They also confirmed the presence of foreign fighters within their ranks and have openly stated that it is working with al-Qaida to remove the government. The listing of al-Shabaab under the Charter of the United Nations Act gives other governments and organizations an international obligation to freeze the assets of persons and entities involved in the commission of terrorist acts. Under the Charter of the United Nations Act, it is a criminal offence to use or deal with the assets of, or to make assets available to, a listed person or entity.

The UN however assists, the Intergovernmental Authority on Development (IGAD) which attempts to coordinate peacekeeping assignment for Somalia. Without the United Nations IGAD remains futile in peacekeeping or peacemaking. For IGAD bombing in Uganda, a country that shares no border with Somalia, was a strong message to those bordering the troubled country; Kenya, Ethiopia and Djibouti. (Francis Njubi Nesbitt, 2010) This came just few weeks before the summit of the African Union in the same nation. 
In the African Union Summit in Kampala, it was stressed the need to increase current number of peacekeepers in Somalia. Each of member states was urged to deploy troops. In order to share the burden with Uganda and Burundi Djibouti, Guinea, and Senegal said to be sending peacekeepers. In the summit however, the AU agreed to send an estimated 4,000 more troops to strengthen AMISOM. Guinea and Djibouti pledged a battalion each. Members of the Inter- Governmental Authority for Development (IGAD) also agreed in early July to send an estimated 2,000 troops (Ted Dagne, 2010).

The concern of the UN is largely humanitarian although without political stability the delivery of humanitarian services will be interrupted. For the same reason the United Nations has warned that Somalia insurgents are posing a serious international security threat and made a renewed appeal to the transitional government to end the civil conflict. The UN secretary general, Ban Ki-moon described the suicide bomb attacks by al-Shabaab as horrific. He further explained that:

"The attacks demonstrated that al-Shabaab remains a serious security threat for Somalia, the sub-regions and the wider international community," (Centre for Community Dialogue, 2010)

The UN constantly reports that the Somalia struggle to cope with casualties caused by al-Shabaab citing thousands of reported deaths in Mogadishu in the year 2010. Overall the UN funds Somalia and funds are currently running out. An additional of $\$ 60$ million has been appealed by the Office of the United Nations High Commissioner for Refugees (UNHCR) to settle the rapidly growing number of refugees within Somalia and four neighboring countries. From that amount, the UNHCR has received only 36 percent of the $\$ 424$ million it needs for Somalia in 2010.The U.N. deputy high commissioner for refugee T. Alexander Aleinikoff stated that:

"The displacement crisis is worsening with the deterioration of the situation inside Somalia, and we need to prepare fast for new and possibly large-scale displacement," (Betwa Sharma, 2010)

The leadership of al-Shabaab have sharply defended the group's unrelenting opposition towards the United Nations.

"Is it reasonable for us to stand cross-armed like this, while the United Nations is making plans to bring more crusade forces hereto occupy our homes and change our religion? Wasn't it the UN which established the TNG... and who gave a green line for the Christians to occupy our lands? ... They considered these [AU] forces less harmful than the Ethiopians, and so... the biggest atheist organization on this planet, notorious for its malevolence towards Islam and Muslims, sent its troops into this Muslim country in order... to twist the Islamic roots away from the lives of Muslims." (Evan F. Kohlmann, 2009)

In July 2009, al-Shabaab banned three UN agencies. The UNDP - the United Nations Development Program; UNDSS - the United Nations Office for Peace and Security; UNPOS - the United Nations Political Office for Somalia are considered, by al-Shabaab, to be hostile to Islam and Muslims. In their investigation al-Shabaab found that this decision of closure and expulsion has been made for these committees involved in activities hostile to Islam and Muslims and their attempts to preclude the formation of an Islamic state in Somalia. In early March 2007, al-Shabaab declared a war on African Union peacekeepers that began arriving in Mogadishu which started escalation of violence into the realm of suicide bombings. To help alleviate the burden on the Ethiopian military, there are 3,400-man force comprised of troops contributed by nearby Burundi and Uganda. But how to create political stability without provoking some essential nationalist animosities among ordinary Somalis? al-Shabaab knows this aspect of the Somalis and employs it, and for the same reason any foreign peacekeeper arriving in Somalia is an illegitimate occupying force. On this note al-Shabaab argued that:

"These people are blind to the reality that sending these [AU] forces will not actually change anything... It is to be assured that our jihad does not target a specific nationality from amongst the crusaders more than any other-rather, it targets any crusader occupier wherever they can be found... The mujahideen understand that there isn't any difference between fighting the Habashis [Ethiopians], the Ugandans, or the Burundians, who came under the pretext of a so-called peacekeeping force... The departure of the occupying Ethiopian forces, and replacing them with another force-whether it belongs to the African Union, the United Nations, or any other national and international organization, and regardless of whatever slogan they brand themselves with, such as 'peacekeeping 
forces'-doesn't change a thing... All these plots, names, and symbols are nothing more than a scheme to replace one occupation with another". (Evan F. Kohlmann, 2009)

\section{Western Government's Views and Policies on Al-Shabaab}

In this section the study will highlight the policies adopted by some Western governments against al-Shabaab. It is important to see the position of the world influential powers such as US, UK, Australia and Canada. On 29 February 2008, the US government designated al-Shabaab as a Foreign Terrorist Organization under Section 219 of the Immigration and Nationality Act (as amended) and as a Specially Designated Global Terrorist under Section 1(b) of Executive Order 13224 (as amended) (Al-Shabaab, the National Counterterrorism Centre).

The US believed that al-Shabaab has used intimidation and violence to undermine the Somali government and threatened civil society activists working to bring about peace through political dialogue and reconciliation. The group scattered leaflets on the streets of Mogadishu warning participants in last year's reconciliation conference that they intended to bomb the conference venue. Al-Shabaab promised to shoot anyone planning to attend the conference and to blow up delegates' cars and hotels. Although al-Shabaab did not carry out these particular threats, the group has claimed responsibility for shooting Deputy District Administrators, as well as several bombings and shootings in Mogadishu. Al-Shabaab leaders have ordered attacks on African Union troops based in Mogadishu.

Given these threats the US felt that the designation will raise awareness of al-Shabaab's activities and help undercut the group's ability to threaten targets in and destabilize the Horn of Africa region (NEFA Foundation, 2009).

The consequences of these designations include a prohibition against the provision of material support or resources to al-Shabaab and blocking of all property and interests in property of the organization that are in the United States, or come within the United States, or the control of U.S. persons. On this, the former Secretary of State Dr. Rice took this action in consultation with the Attorney General and the Secretary of the Treasury.

The US is of the opinion that designations play a critical role in our fight against terrorism and are an effective means of curtailing support for terrorist activities and pressuring groups to renounce terrorism. Al-Shabaab, the US government opined, is a violent and brutal extremist group with a number of individuals affiliated with al-Qaida. Many of its senior leaders are believed to have trained and fought with al-Qaida in Afghanistan (Department of State, 2010). On April 13, 2010, the White House issued a strongly worded statement directing the Treasury Department to freeze the assets of more al-Shabaab figures. The President declared a national emergency to deal with the unusual and extraordinary threat to the national security and foreign policy of the United States posed by al-Shabaab.

However, it is interesting to note that the designation lifted al-Shabaab's domestic and global stature among Salafi- jihadist groups (Abdirahman Aynte). In fact, al-Shabaab favorably hailed the designation as an honor, and further mocked the United States "our only regret is that we are number 41 on that list, not number one" (Abdirahman Aynte). In principle they father argued that:
"Terrorizing non-Muslims who come to your land (Somalia) is a religious obligation...was quoted as clearly enjoying the profile they believe al-Shabaab has been "promoted" as terrorizing as what he calls "American backed Ethiopian invaders" and showed no regrets nor remorse but glorification of his organization in the eyes of God. He says "while the greatest evil calls us terrorist, God calls us the undefeatable Mujahidiin". They add "anyone America calls a terrorist is one step closer to God's glory and reward as a good Muslim who defends Islam and resources of Muslims worldwide against America" (Abdisaid M. Ali, 2008).

In the first week of March 2010, British government added Somali al-Shabaab group to their respective list of proscribed terror groups. The decisions mean that it will now be illegal to fundraise or support al-Shabaab in the nation. The decision made to proscribe follows a series of stories indicating that steady streams of young men are going abroad to fight in East Africa. The government also realized that some young Britons are joining the group. Raffaello Pantucci claimed that almost a dozen British Muslims had left the U.K. to join al-Shabaab in Somalia. This was including some students from the prestigious London School of Economics and King's College London (Raffaello Pantucci, 2008).

Furthermore, there is a clear sense of growing trepidation surrounding Somalia's al-Shabaab. There is at least two of the attempted bombers and a substantial number of the support network involved in the July 21, 2005 plot 
to attack London's public transport system were of Somali extraction. It was reported that the plots emerged from the Somali Diaspora community there (Tariq Panja, 2007). It also was believed that those individuals from the Diaspora were drawn into plots fostered by local networks to prepare for large-scale domestic attacks. Moreover, the UK government attempted to shut down what it believed to be an al-Shabaab fundraising and support network last year, though they did not stand up in court. In consequences, there has been a greater law enforcement focus on Shabaab (Tariq Panja, 2007). In their reaction to the designation, al-Shabaab held a press conference in Mogadishu to announce the group was "saddened" by the British decision.

The Australian government has listed al-Shabaab as a terrorist organization in August 21, 2009, under the Division 102 of the Criminal Code and the Charter of the United Nations Act. The listing follows advice from security agencies that al-Shabaab is either directly or indirectly engaged in, preparing, planning, assisting or fostering terrorist acts. Australia listed five weeks after arresting five Australian men, allegedly al-Shabaab, planning to conduct a suicide attack on an army base in Sydney. Australia is preparing its policies force to deal with treats from al-Shabaab on its homeland (Robert McClelland, 2009). The listing of al-Shabaab under the Criminal Code means that it will be an offence to be a member of, associate with, train with, provide training for, receive funds from, make funds available to, direct or recruit for al-Shabaab (Australia National Security, 2009). In their review of listing al-Shabaab as a terrorist organization, Australian government viewed that al-Shabaab is the most prominent of the militia groups that has emanated from the Islamic Courts. The government further opined that al-Shabaab encompasses a range of elements, ranging from those focused solely on the domestic insurgency in Somalia to elements that support al-Qaeda's global ideology of violent immoderation. Elements of al-Shabaab are linked to al-Qaeda through leadership contacts and training, both recent and historical, and by al-Qaeda senior leadership endorsement of its activities (Australia National Security, 2009). The government of Canada listed al-Shabaab as a terrorist organization effective March 5, 2010, pursuant to the Criminal Code of Canada. Prior to this announcement it was reported that in early 2009, that a group of six young Somali Canadians disappeared from their local community in Toronto, suggesting that they had ended up in the hands of al-Shabaab in Somalia (Raffaello Pantucci, 2009). The designation was decided when government received a report that al-Shabaab try to radicalize and recruit young Canadians. Confirming the government passion on this, the Canadian Minister of Public Safety detailed the fact that:

"The government is taking this step to help protect Canadian families from the activities of this organization. The government received reports from the Somali community that al-Shabaab has attempted to radicalize and recruit young Canadians. The listing of al-Shabaab will help the government of Canada to better support the Somali community of Canada." (Public Safety Canada, 2010)

The Canadian government further acknowledged that al-Shabaab is the strongest, best organized, financed and armed military group in Somalia, and it controls the largest stretch of territory in Southern Somalia.

"An Islamist group dedicated to establishing a Somali caliphate, waging jihad against the enemies of Islam, and removing all foreign forces and Western influence from Somalia. It is today the strongest, best organized, financed and armed military group in Somalia, and it controls the largest stretch of territory in Southern Somalia." (BBC News, 2010)

Canada will not tolerate terrorism and is determined that terrorist groups do not receive support from Canadian sources. The Minister lamented that

"Listing this group is another example of the decisive action needed to make

Canada's communities safe. Canada is once again showing vigilance in the global

fight against terrorism." (Public Safety Canada, 2010)

No doubt that the decision to list al-Shabaab meets the legal threshold set out in the Criminal Code, which requires the existence of reasonable grounds to believe that the entity has knowingly participated in or facilitated a terrorist activity or is knowingly acting on behalf of, at the direction, or in association with such an entity. By listing Al-Shabaab in the terrorist list, the Canada government foresees will help combat terrorist activities, including impeding terrorist financing. Responding to the designation by Canada, al-Shabaab condemned the Canadian designations, claiming some Western nations were trying to find ways of looting the properties of Somali Muslims living in their countries (Raffaello Pantucci, 2009).

\section{Al-Shabaab's Recruitment Exercises in Major Western Countries}

It is an open secret that al-Shabaab welcomes Muslims foreign fighters, without any discrimination on the basis of nationality. In fact, in May 2008, al-Shabaab's leadership acknowledged that it needed to magnetize willing 
and experienced foreign recruits if it hoped to achieve its goals of establishing an Islamic state and contributing to the global jihad. The leadership argued that:

\begin{abstract}
"We seek to empower the shari'a of Allah and commit His faith to His worshippers, in perfect conformity between the global jihad and the jihad in Somalia. However, [we] lack the precious element of the foreign fighters. There are an insufficient number of non-Somali brothers." (Christopher Harnisch, 2010)
\end{abstract}

Therefore, al-Shabaab started to develop and implement a robust and effective international recruiting strategy that has helped it expand its control in Somalia. At the same time, they struggled to raise funds, execute high-profile and sophisticated terror attacks. The recruiting strategy has focused on attracting two main groups which the first one is focusing on the global jihad. Meanwhile, the second and more specific group is young ethnically Somali Muslim men living abroad who seek both to fight in the global jihad and to defend their homeland (Christopher Harnisch, 2010). As a result of that strategy, it was believed that in late 2007, dozens of young men of Somali from Diaspora communities in the West have disappeared and understood returning to Somalia to take up arms or to train in al-Shabaab camps.

In the United States, this group of individuals can be divided into two subgroups that are converts and Somali-Americans. However, the members of this convert Americans were not recruited but instead volunteered. The exact figure of Somali Americans remains mysterious but about 25 cases have been confirmed and fairly well-documented. Michael Taarnby, 2010) The Minneapolis-St. Paul area is the place of 70,000 Somalis reside and it is clearly the Minneapolis area that is of greatest concern. According to the government sources about 20 young Somalis from Minneapolis have left for Somalia. From the information given, it was believed that the first group departed in the fall of 2007.

However, some stayed in stateside but keep in touch via Face book with their friends. This long-distance recruitment scheme seems worked well. Hence, a year later a second wave of recruits emerged. Besides that, there are credible reports of disappearances in other American cities with large Somali populations such as Seattle, Boston, San Diego, Columbus, Ohio, and Portland, Maine (Ken Menkhaus, 2009).

In most cases, the recruiters for al-Shabaab approached the mosque leadership. One of the cases involved a 25year-old who currently pleaded guilty to providing material support to terrorists based on his travel to Somalia to train with al-Shabaab. The director of one of the community Centers in Minneapolis told the media that recruiters approached the young man at one of the mosques in the vicinity. The attorney Paul Engh corroborated the account who filed a motion to amend the conditions of the detention that speaks of how recruiting young men to serve as suicide bombers is the definition of evil and this recruitment happened at a place of worship (Daveed Gartenstein-Ross, Madeleine Gruen, and Sara R. Westfall, 2009).

The government also claims that some young Somalis received phone calls and others attended secret meeting. The second case confirmed this technique which engaged a 26-year-old who also pleaded guilty to the same charges. He appealed that the recruiters that helped draw him to Somalia, mentioning secret meetings beginning in October 2007 with people he would only describe as "guys." (Gartenstein-Ross.Daveed, 2009)

The authorities have so far identified one possible recruiter in the Minneapolis area. According to them he is an active recruiter in the U.S. with a high standing in the community. It is stated that he contacted young Somalis through emails, phone calls and conversations in internet chat rooms and putting pressure on them, thus they will join the fight. According to Stephen Smith, an attorney who represents several young Somalis questioned by authorities, this particular recruiter is someone with audacity and able to appeal to young Somali-Americans.

“...Someone with a bravado that appealed to younger men he met on the basketball court or at mosques. ... an 18-year-old got a phone call from him in Somalia, asking him to join the fight... he and the teenager also exchanged e-mails and had a brief conversation in a chat room, ...the teen didn't go but felt uncomfortable turning down someone he looked up to. The recruiter's whereabouts aren't known. Some family members say they believe he was killed in Somalia [in July 2009], but federal officials could not confirm that." (Daveed Gartenstein-Ross, Madeleine Gruen, and Sara R. Westfall, 2009)

It is confirmed that one of the young Somali-American was killed in Mogadishu in June 2009 after going missing from the Twin Cities area. His nephew, when the American authorities contacted him for information pointed his finger at a mosque and this was used in the Senate testimony (The Investigate Project of Terrorism, 2010). He 
claimed that the mosque's management painted family members who spoke out about the disappearances as bad people. In the interview, he mentioned that:

"We have been threatened for just speaking out. Some members of the mosque told us that if we talk about the issue, the Muslim center will be destroyed and Islamic communities will be wiped out. They tell parents that if they report their missing kid to the FBI that FBI will send the parents to Guantanamo Jail." (Osman Ahmed, 2009)

The Canadian government believed that about 20 Canadians have joined al-Shabaab. Recently, the pattern of puzzling disappearances has been recurring. It was reported that a group of young men from Toronto disappeared in November 2009. Meanwhile, in late 2009 at least half a dozen have gone missing within three months. Among the missing were university students (The Investigate Project of Terrorism, 2010). Parents of these young Somali-Canadians were bewildered by the disappearances of these individuals, most of the cases left without notification. A few had called home saying that they were in East Africa.

In the Canadian experience the recruitees are not young men who struggled to adjust to life in the West. They were in their early 20 s to early 30 s and all attended in one mosque. At least two were born in Canada. The others were educated here from primary school onwards. They attended either college or university. Study also shows that they were well integrated into the mainstream Canadian society. Community leaders in Canada were taken by surprise as these young men are of respected families who valued education, some have found work and integrated into the broader community (Joe Friesen and Colin Freeze, 2009). The authorities are certain of the possibility of recruiter, travelling frequently between Canada and Somalia. It is also believed that these recruiters in most cases left the county and orders the recruited to follow.

"I am told that the person who recruited them left the country before them and then made arrangements for them to follow him." (Joe Friesen and Colin Freeze, 2009)

The Somali Diaspora in Australia has also been affected by the international reach of al-Shabaab. According to the authorities there are approximately about 10 to 20 young Somali-Australians returned to fight alongside with al-Shabaab. The real number however may be double according to security officials. The officials are arguing that some have been killed in battle field although it is unlikely to obtain accurate verification (Michael Taarnby, 2010). In a related development, in August 2009 four men were detained by the security authorities on suspicion of planning terror attacks on army barracks. Two of the arrested were Somali-Australians Authorities are convinced that they travelled from Melbourne to Somalia to link up and train with al-Shabaab. Altogether, there are about 18 people of Lebanese and Somali origin suspected in this case (John Solomon, 2009).

Security official have argued that this case was exposed after one of the Lebanese-Australian called another conspirator to request assistance to travel to Somalia with some other friends. The government is not ruling out the possibilities or the intention of joining al-Shabaab. Like other countries the security has identified a facilitator who has a close contact with al-Shabaab. Reports say that the facilitator acted as a middle man that would arrange for funding, logistics and travel (John Solomon, 2009).

The United Kingdom has the largest Somali population in Europe, around 250,000. It was reported by The Times of London that British security services believe that dozens of Islamic extremists have returned to Britain from terror training camps in Somalia. Peter Neumann of the International Centre for the Study of Radicalizations and Political Violence at King's College, London, told a British news outlet:

"The numbers I hear (going from Britain to Somalia) are 50, 60 or 70, but in reality we don't know." (DaveedGartenstein-Ross, Madeleine Gruen, Sara R. Westfall, 2009)

The Independent news reported two Somalia brothers from London were among those who joined al-Shabaab forces are believed to be bodyguards to one of the commander.

In a similar case, earlier in 2007, a young British Muslim was link to suicide bomb incident in Baidoa. He later appeared in al-Shabaab propaganda material, becoming the first known British suicide bomber in Somalia after he blew himself up at a checkpoint in Baidoa in October 2007, killing more than 20 Ethiopian soldiers (Michael Taarnby, 2010).

Netherlands has approximately 22,000 Somalis this makes the existence of al-Shabaab less prominent in the country. The pattern of radicalization also is much of a smaller scale (Michael Taarnby, 2010). In one case in October 2009, four Dutch nationals were arrested near the Somalia border and, on suspicion grounds; they were arrested of helping al-Shabaab, with no sufficient evidence to prosecute them. 
According to their travel documents, they are all aged 21 years; three were of Moroccan origin, whereas the other was a Somalia. In a related development, the Dutch Justice Department revealed that one Dutch national had been arrested earlier in Azerbaijan. This 2005 incident was also based on suspicion grounds; the person was accused of attempting to join the Jihad (Michael Taarnby, 2010).

In a separate incident, a Somali citizen has been arrested at a refugee center in Dronten in November 2009; he is believed to have been in Holland since December 2008 and occasionally acted as an intermediary to facilitate the travel arrangements to join the training camps of al-Shabaab in Somalia. Since he stayed in Minneapolis before moving to Europe the United States has asked Netherlands for extradition, provided that suspicions are confirmed (Michael Taarnby, 2010).

\section{Recruitment in Scandinavian Nations}

Recruitment to al-Shabaab in Scandinavia has been quite extensive over the past years. Estimates vary approximately from 25 to more than 80 of whom the majority has been Somalis. The higher figure includes community based estimates, and may be somewhat exaggerated. Two Scandinavian country studies will be covered in more detail here, because of confirmed cases, and these are Sweden and Denmark. Norway has also been exposed to this trend, but apparently to a lesser degree. Two Norwegian citizens were reported to have been arrested in Mogadishu and at least 13 youth from Oslo area are suspected of having been recruited by al-Shabaab according to media reports (Michael Taarnby, 2010).

Sweden's security service SAPO believes that about 20 to 30 people have left Sweden to join al-Shabaab. This includes people of various ethnicities, not just Somalis. Sweden takes a prominent role in the recruitment to Somalia because of the actual numbers of Swedish citizens or residents who have joined the insurgents.

Equally interesting is the current role of a former imam in Sweden who presently occupies a senior position in al-Shabaab. Of these involved, about five have been killed in fighting and ten are still believed to be active in Somalia. The security service added that this number might be higher, since the traffic is ongoing and increasing. (John Solomon, 2009). The Swedish fighters are primarily of Somali origin. However, individuals with other ethnic backgrounds have also been attracted, and they are between the age of 20 and 30. The pattern of disappearance resembles other countries where these young men have left without telling their families. Authorities rely on information that al-Shabaab has been especially active in the Stockholm suburb of Rinkeby, where a large number of Sweden's Somali population resides. It was reported by a youth leader at a Rinkeby community center that he saw four young men recruit Somalis in a public square (John Solomon, 2009).

"They talked about jihad and what was happening in Somalia. That it was right to go there and that they'd help you out with a plane ticket if you needed it." (John Solomon, 2009)

In 2007 at least one case involving Swedish couple who was arrested by the Ethiopian intelligence service in Mogadishu was suspected having terrorist affiliations and thus was detained for three months but was later returned to Sweden. However, they were arrested once again in Pakistan in August 2009 in the company of former Guantanamo inmate Mehdi Ghezali, also from Sweden. Pakistani authorities suspected the group of foreigners, who also included other nationalities, of travelling to a terrorist meeting in Waziristan (John Solomon, 2009).

In a rather peculiar trend Sweden has nationals who left the country for good to resettle in Somalia. These nationals had actively supported al-Shabaab for an extended period. This tactical attitude is rather dangerous as it is used to encourage others of the same tendency living in Europe to move back to Somalia. They further incite that, living among infidels was an unacceptable in Islam and use their own example (John Solomon, 2009).

The idea of recruitment by al-Shabaab was first rumored in Denmark in 2006. Generally this was a support to the ICU. In December 2006, the former Somali TNG government grumbled that recruitment was taking place in Denmark. Later the Danish media reported that its nationals had been apprehended in neighboring countries in early 2007 as they attempted to escape from the fighting in southern Somalia (John Solomon, 2009).

In Denmark the Somali community is widely aware of the movements to Horn of Africa, in fact the community leaders regularly express concern over the situation. It is estimated that about 15 Somalis from Jutland, Denmark had gone to Somalia to train or fight with al-Shabaab and these leaders further assume that even more had left from Sealand. Other Somalia community leaders in Denmark claimed that about 50 young men have left to join al-Shabaab, with no independently verified account (John Solomon, 2009).

In December 2009, the first Danish suicide bomber shocked the Somali community in Denmark. The bomber has been identified as 24-year-old who detonated explosives hidden under his clothes during a graduation ceremony 
for Somali medical doctor's graduation ceremony at the Shamo Hotel in Mogadishu in December 2009. This incident took the life of more than 24 people, including four government ministers, and injured more than 40 . Al-Shabaab denied responsibility for the bombing instead blamed TFG officials who had acted suspiciously. The bombing caused considerable outrage in Mogadishu because of the senseless violence that specifically targeted one of the most needed groups of professionals in Somalia. The suspected of the suicide bomber came to Denmark at the age of five and spent the next 15 years in a suburb of Copenhagen.

\section{References}

Sanderson Beck, UN Peacekeeping during the Cold War: History of Peace, World Peace Effects since Gandhi. World Peace Communication, Vol. 2.

Bradbury, M. (2009). The Search for Peace: A History of Mediation in Somalia Since 1988, Inter peace and the Center for Research and Dialogue.

United Nations Political Office for Somalia (UNPOS). [Online] Available: http://unpos.unmissions.org/Default. aspx?tabid $=1912$

Nesbitt, F. N. (2010). Al-Shabaab's Wakeup Call, Foreign Policy in Focus (FPIF). [Online] Available: http://ww w.fpif.org/articles/al-shabaabs_wakeup_call (July 26, 2011).

Dagne, T. (2010). Somalia: Current Conditions and Prospects for a Lasting Peace, Congressional Research Service, October 8.

Centre for Community Dialogue (CCDS). (2010). The UN says the Al-Shabaab Group is increasingly posing a Serious International Security Threat. [Online] Available:http://www.rondoon.com/2010/09/the-un-says-the-al-s habab-group-is-increasingly-posing-a-serious-international-security-threat/ (September 14).

Sharma, B. (2010). UN Grapples With Failed State of Somalia. AOL News, May 15.

Kohlmann, E. F. (2009). Migration and Jihad in the Horn of Africa. [Online] Available: www.nefafoundation.or g

Al-Shabaab. The National Counterterrorism Centre. [Online] Available: http://www.nctc.gov/site/groups/al_shab aab.html

Designation of Al-Shabaab, NEFA Foundation, (2008). [Online] Available: http://www.nefafoundation.org/misc ellaneous/FeaturedDocs/StateDept_AlShabaabDesign.pd

State Department (2008). Designation of al-Shabaab as a Foreign Terrorist Organization, Office of the Coordinator for Counterterrorism, February 26, Volume 73, Number 53.

AbdirahmanAynte Ali. The Anatomy of Al-Shabaab,p.3-4/54. [Online] Available: http://www.scribd.com/doc/ 34053611/The-Anatomy-of-Al-Shabaab-by-Abdi-Aynte

Abdisaid, M. A. (2008). The Al-Shabaab Al-Mujahidiin: A Profile of the First Somali Terrorist Organisation, InstitutfürStrategiePolitikSicherheits und Wirtschaftsberatung (ISPSW), Berlin, Germany.

Pantucci, R. (2010). Al-Shabaab Proscribed in Canada and the United Kingdom, Terrorism Monitor, March 19, Vol. 8 Issue 11.

Panja, T. (2007). The Washington Post, July 9.

Robert McClelland MP, Stephen Smith MP. (2009). Listing of Al-Shabaab as a Terrorist Organization, 21 August.

Australia National Security, Al-Shabaab. August 21.

Pantucci, R. (2009). American Jihad: New Details Emerge About al-Shabaab Recruitment in North America. Terrorism Monitor, December 3, Vol. 7 Issue 37.

Public Safety Canada. (2010). The Government of Canada lists Al-Shabaab as a terrorist organization, March 7.

BBC News. (2010). Somali group added to terrorist list, March 8.

Harnisch, C. (2010). Katherine Zimmerman, The Terror Threat from Somalia: The Internalization of Al-Shabaab, A report by Critical Threats Project of the America Enterprise Institute, February 12.

Taarnby, M. (2010). The Internationalization of Militant Islamism in Somalia and the Implications for Radicalization Processes in Europe, Copenhagen, DK; Danish Ministry of Justice, February 26.

Menkhaus, K. (2009). Violent Islamic Extremism: Al-Shabaab Recruitment in America. Davidson College, North Carolina, March 11. 
Gartenstein, R. D. (2009). Madeleine Gruen, Sara R. Westfall, Al-Shabaab Recruiting in the West, Foundation of Defense Democracy (FDD), November 4.

Gartenstein, R. D. (2009). Western Recruits in Somalia. [Online] Available: http://www.daveedgr.com/publicati ons/popular-press/western-recruits-in-somalia/

The Investigate Project of Terrorism (IPT News). (2010). Jihadist Recruitment's Human Toll: One American Family's Experience. [Online] Available: http://www.investigativeproject.org/1763/jihadist-recruitments-humantoll-one-american (January 29, 2012).

Ahmed, O. (2009). Al Shabaab Recruitment in America. United State Senate Homeland Security and Governmental Affairs Committee, March 8.

Friesen, J \& Freeze, C. (2009). Are Somali-Canadians fighting for the shadowy al-Shabaab?, The Globe and Mail Post. [Online] Available:http://www.theglobeandmail.com/news/national/toronto/are-somali-canadians-fig hting-for-the-shadowy-al-shabab/article1389876/page1/ (December 04, 2011).

Solomon, J. (2009). Al-Shabaab's Tentacles Extend West, Newsletter by World-Check, September. 